\title{
The BRAINS Study: Safety, Tolerability, and Dose-finding of Repinotan in Acute Stroke
}

\author{
Philip Teal, Frank L. Silver, Denis Simard
}

\begin{abstract}
Background and Purpose: Repinotan is a potent, serotonin (5- $\mathrm{HT}_{1 \mathrm{~A}}$ ) full receptor agonist that interferes with ischemiamediated neuronal cell death in animal models. This double-blind, placebo-controlled phase II study examined the safety, tolerability, and dose of repinotan in patients with acute ischemic stroke. Methods: Patients with acute hemispheric ischemia and a National Institutes of Health Stroke Scale of 4 to 25 were randomized to placebo or repinotan $0.5,1.25$, or $2.5 \mathrm{mg} / \mathrm{day}$ (d) given by continuous intravenous infusion for 72 hours. Treatment was started within six hours of symptom onset. Evaluations were performed at four weeks and three months. Results: Among 240 patients in the safety analysis, repinotan was well-tolerated, with adverse events appearing more frequently in the highest dose group $(2.5 \mathrm{mg} / \mathrm{d})$. The most common adverse event was headache $(21.3 \%$ to $35 \%$ with repinotan and $24.1 \%$ with placebo). Most (75\%) adverse events were of mild or moderate severity. The most common severe adverse events were neurological worsening, cerebral hemorrhage, and brain edema. The number of deaths and serious adverse events were similar among placebo and repinotan groups. Compared to the placebo group, the proportion of patients with good outcomes at three months was greatest in the group receiving repinotan $1.25 \mathrm{mg} / \mathrm{d}$, although the difference was not statistically significant. Conclusions: This study indicates that the incidence of adverse events was comparable with all doses of repinotan and placebo, and no safety issues were observed. A trend toward better tolerability with evidence of efficacy was observed with the repinotan $1.25 \mathrm{mg} / \mathrm{d}$ dose.
\end{abstract}

RÉSUMÉ: Étude BRAINS: sécurité, tolérance et détermination de la dose du repinotan dans l'accident vasculaire aigu. Introduction et objectif: Le repinotan est un agoniste puissant du récepteur de la sérotonine (5-HT1A) qui interfère dans la mort neuronale médiée par l'ischémie chez les modèles animaux. Cette étude de phase II, à double insu, contrôlée par placebo, évalue la sécurité, la tolérance et la dose de repinotan chez des patients atteints d'accident vasculaire cérébral ischémique aigu. Méthodes: Des patients atteints d'ischémie hémisphérique aiguë et ayant un score de 4 à 25 au National Institutes of Health Stroke Scale ont été répartis au hasard au groupe recevant un placebo ou au groupe recevant du repinotan à 0,5, 1,25 ou $2,5 \mathrm{mg} / \mathrm{j}$ en infusion intraveineuse continue pendant 72 heures. Le traitement était commencé dans les six premières heures du début des symptômes et les patients étaient évalués 4 semaines et trois mois après le traitement. Résultats: L'analyse des données sur la sécurité chez 240 patients a montré que le repinotan était bien toléré et que les incidents thérapeutiques étaient plus fréquents chez les patients qui avaient reçu la dose la plus forte (2,5 mg/j). L'incident thérapeutique le plus fréquent était la céphalée (21,3\% à $35 \%$ pour le repinotan et $24,1 \%$ pour le placebo). L'intensité de la plupart des incidents thérapeutiques était légère ou modérée. Les incidents thérapeutiques graves les plus fréquents étaient la détérioration neurologique, l'hémorragie cérébrale et l'oedème cérébral. Le nombre de décès et d'incidents thérapeutiques graves étaient semblables dans les deux groupes. La proportion de patients ayant une issue favorable après trois mois était plus élevée dans le groupe ayant reçu le repinotan à la dose de $1,25 \mathrm{mg} / \mathrm{j}$ comparé au groupe ayant reçu le placebo, mais la différence entre ces deux groupes n'était pas significative. Conclusions: Dans cette étude, l'incidence des incidents thérapeutiques était comparable quelle que soit la dose de repinotan par rapport au placebo et aucun problème relié à la sécurité du produit n'a été observé. On a observé l'efficacité du repinotan à la dose de $1,25 \mathrm{mg} / \mathrm{j}$. et une tendance à une meilleure tolérance du médicament.

Can. J. Neurol. Sci. 2005; 32: 61-67

Stroke is the third most common cause of death and the leading cause of chronic disability in North America. ${ }^{1}$ While the prevention of ischemic stroke has improved over recent decades, only tissue plasminogen activator (t-PA) given within the first three hours after onset of symptoms has been approved for acute stroke therapy. ${ }^{2}$ The restrictive three-hour therapeutic window, ongoing safety concerns, exclusion criteria, and the need for skilled stroke teams has limited delivery of t-PA to only a small proportion of stroke patients. Neuroprotective agents with a longer potential treatment window and broader clinical applications are needed to both complement t-PA and serve as effective monotherapy.

From the University of British Columbia, Vancouver, British Columbia, (PT); The Toronto Hospital, Western Division, Toronto, Ontario, (FLS); Hopital de L'EnfantJesus, Quebec City, Quebec, (DS); Canada

ReCeIVEd APRIL 8, 2004. ACCEPTEDinfinAlform SePtember 1, 2004. Reprint requests to: Philip Teal, Division of Neurology, University of British Columbia, The Fairmont Medical Building, 810-750 West Broadway, Vancouver, BC V5Z 1 H7 Canada. 
While many neuroprotectants have been tested in animal stroke models, none have yet proven to be safe, well-tolerated, and effective in clinical trials of acute ischemic stroke. ${ }^{3-14}$ Repinotan is a potent full agonist at the serotonin $\left(5-\mathrm{HT}_{1 \mathrm{~A}}\right)$ receptor. ${ }^{15}$ In animal models, repinotan demonstrated neuroprotectant activity over a broad range of doses for up to five hours postischemia ${ }^{15-17}$ and was well-tolerated with no safety concerns in healthy volunteers. ${ }^{18}$ The primary objective of this phase II Bayer Randomized Acute Ischemia Neuroprotectant Study (BRAINS) was to evaluate the safety and tolerability of three doses of intravenous repinotan in patients with acute ischemic stroke.

\section{METHODS}

This was a multicenter, randomized, double-blind, placebocontrolled study of the safety and tolerability of repinotan in patients with acute ischemic stroke. The study was carried out in accordance with United States and Canadian regulatory requirements and in accordance with International Conference on Harmonization - Good Clinical Practice Guidelines. The study protocol was approved by an appropriate Institutional Review Board at each study site. Patients or their legally authorized representatives gave written informed consent before initiation of treatment.

An independent Safety Monitoring Committee (SMC) was established prior to the start of the study. The SMC reviewed data in a blinded manner after treatment of $25 \%, 50 \%$, and $100 \%$ of patients, and serious adverse events were reported to the chairman of the SMC.

\section{Patient Population}

Patients with a suspected stroke consistent with acute cerebral hemispheric ischemia of thromboembolic origin were recruited from 31 university and community medical centers in Canada and the United States. Patients were required to be at least 18 years old with a neurological deficit, no signs of improvement for a minimum of one hour, and a National Institutes of Health Stroke Scale (NIH-SS) ${ }^{19}$ total score of 4 to 25 with a motor deficit $\geq 2$ and a level of consciousness $<2$.

Patients were excluded if there was intracerebral hemorrhage on computed tomography (CT) scan, if any finding was inconsistent with an acute ischemic hemispheric stroke, or if the stroke involved the posterior circulation (the brain stem or cerebellum). Patients were ineligible if any other neurological or psychiatric condition was present that possibly would affect functional status, including a previous stroke with significant residual deficit. Patients with severe cardiovascular problems and those with significant hepatic, renal, or other clinically significant disease states were not candidates. Patients were not permitted to receive t-PA during the study.

\section{Baseline Evaluations}

All patients underwent a baseline assessment, which included a complete history and physical examination, vital signs assessment, 12-lead electrocardiogram (ECG), chest radiograph (if clinically indicated), complete neurological examination, and CT scan. The NIH-SS and a historical Rankin Scale ${ }^{20}$ were performed and blood was drawn.

\section{Study Treatment}

Eligible patients were randomized to repinotan 0.5, 1.25, 2.5 $\mathrm{mg} / \mathrm{d}$ or placebo. Randomization was accomplished with a computer-generated list provided by the study sponsor. Sequential numbers in blocks of four were provided to each study center. Repinotan was supplied as lyophilized powder in vials containing $0.4,1.0$ and $2 \mathrm{mg}$ of active drug and was stored at room temperature and protected from light. Immediately prior to use, repinotan was reconstituted with $100 \mathrm{~mL}$ normal saline. The reconstituted solution was stable for 24 hours at room temperature. Study drugs were given for 72 hours by continuous intravenous infusion $(5.2 \mathrm{~mL} /$ hour $)$ starting no later than six hours after the onset of stroke symptoms. All standard therapies used in the management of acute stroke patients were allowed at the discretion of the investigator with the exception of prohibited medications. Physical, occupational, and speech therapies were initiated as appropriate. The co-administration of serotonin receptor agonists or antagonists, selective serotonin reuptake inhibitors or monoamine oxidase inhibitors, and medications known to interact with the cytochrome P450 2D6 (CYP2D6) pathway were prohibited during study drug infusion and for 24 hours postinfusion. Repinotan is metabolized by cytochrome P450 2D6; to detect patients who were poor metabolizers, venous blood samples were collected at six and 10 hours to measure plasma repinotan levels. The sample was immediately analyzed by an enzyme-linked immuno-absorbent assay (ELISA). The study investigator was blind to the ELISA results unless the plasma repinotan level was above $15 \mathrm{ng} / \mathrm{mL}$, in which case the investigator was notified and the repinotan infusion was discontinued to avoid possible further drug accumulation. All patients were followed according to protocol, regardless of the duration of therapy.

\section{Study Assessments}

Patients were monitored closely and assessed daily in a stroke unit or intensive care unit for the duration of study drug treatment and up to 24 hours following its completion. Safety and efficacy assessments were completed at four weeks and three months poststroke. The primary safety parameters were mortality, premature termination from study participation, and adverse events defined by COSTART (an international coding system for adverse drug events) according to intensity, severity, and relationship (assessed continuously to discharge and then at four weeks and three months). Changes in laboratory findings (24h, 96h, four weeks), vital signs (every (q)15min x 1h, q1h x 24h, then q4h until 96h), 12-lead ECG (24h, 96h, four weeks), and neurological findings ( $\mathrm{q} 2 \mathrm{~h} \times 12 \mathrm{~h}, \mathrm{q} 4 \mathrm{~h} \times 12 \mathrm{~h}$, then $\mathrm{q} 8 \mathrm{~h}$ until 96h) were also noted. Serious adverse events were defined as those events that were life threatening, disabling, or resulted in hospitalization or prolongation of hospitalization and occurring during or within seven days of study completion. Deaths occurring within 30 days after the last visit were also included. The NIH-SS was used to assess neurological recovery and was performed by a neurologist certified in its administration according to standard published guidelines. Functional improvement was assessed with the Barthel Index $^{21}$ and the modified Rankin Scale.

\section{Patient Withdrawals}

Patients were withdrawn from the study if an adverse event or 


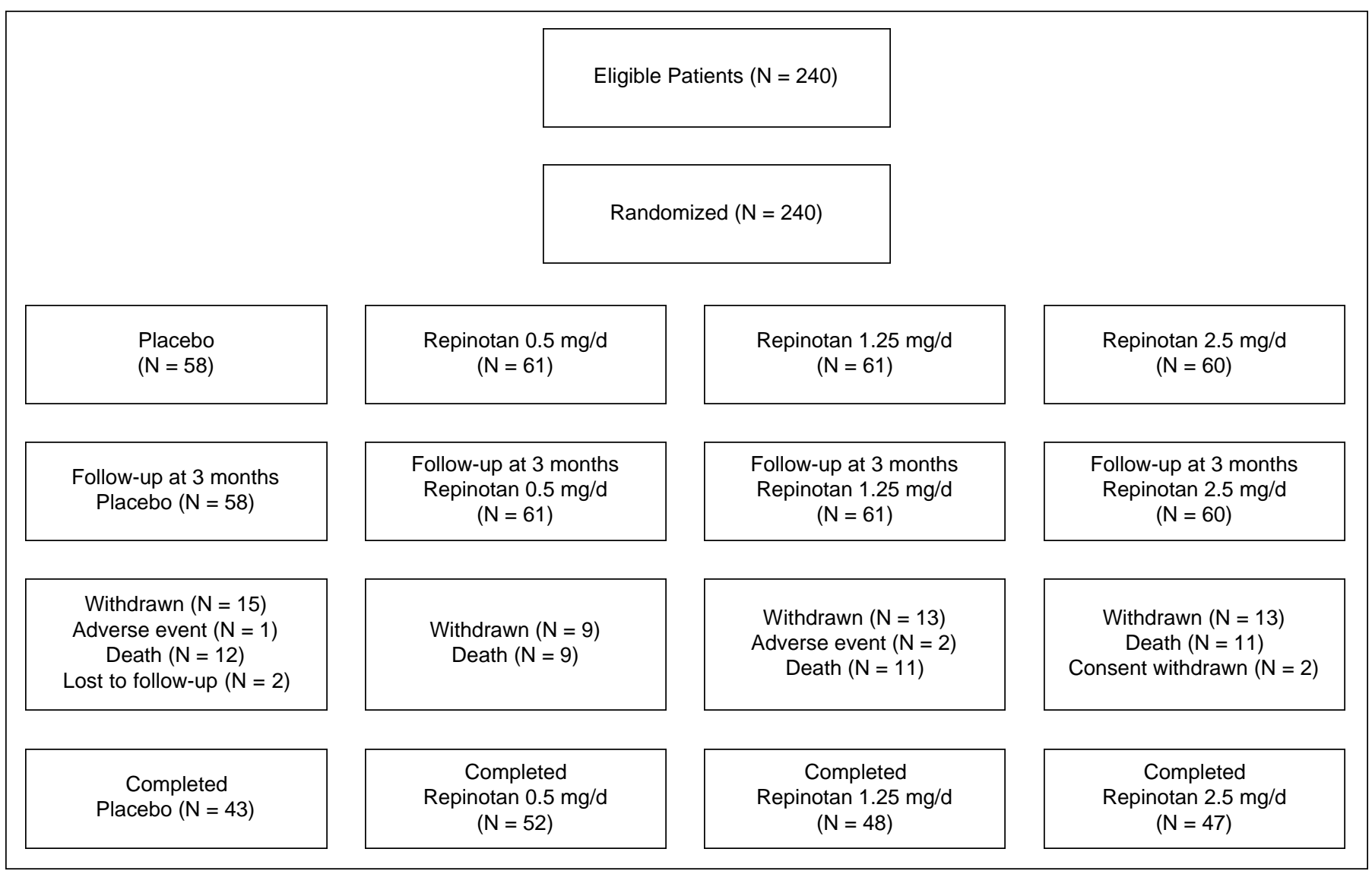

Figure: Flow diagram of patient disposition for the intent-to-treat population.

laboratory abnormality was considered clinically significant, an adverse event was serious, there was noncompliance with the protocol, or the plasma level of repinotan was $>15 \mathrm{ng} / \mathrm{mL}$. These patients were excluded from the prespecified per-protocol analysis but follow-up was continued. Any patient who discontinued prior to completion of drug administration was defined as a premature withdrawal and was followed to the threemonth poststroke visit. If a patient was removed due to an adverse event, follow-up was according to established, acceptable medical practice until resolution of the event or study completion.

\section{Statistical Methods}

All patients randomized to treatment and who met all the inclusion criteria were included in the intent-to-treat (ITT) population. Data were analyzed by the study sponsor using a Statistical Analysis System package. Baseline characteristics and changes in laboratory values, vitals signs, neurological assessments, and ECG were summarized with descriptive statistics. Success rates were assessed with the NIH-SS, Barthel Index, and modified Rankin Scale. A successful response was defined as a 4-point improvement from baseline or a return to normal (0-1) on the NIH-SS, a score of 85 to 100 on the Barthel Index, or a score of 0 or 1 on the modified Rankin scale. Success rates were compared between treatment groups with the Mantel-
Haenszel test and summarized using relative risk and 95\% confidence interval (CI). The 30-day mortality rate and 95\% CI were determined. All statistical tests were two-sided at the $\alpha=$ 0.05 level.

\section{RESUltS}

The ITT analysis included 240 patients who were randomized and received at least part of the study drug infusion. Of these, 50 patients $(20.8 \%)$ withdrew from the study prematurely, including 36 who withdrew after hospital discharge (Table 1 and Figure). The per protocol population comprised 187 patients who completed the treatment protocol with no major protocol violations. Of the 53 patients excluded from the per-protocol analysis, 34 were ELISA-positive. At baseline, no important differences were observed between treatment groups for demographic characteristics, including mean age, mean NIH-SS score, and prior history (Table 2). Compared with the placebo group, patients in the repinotan-treated groups were more likely to have a history of prior neurological disability, prior strokes, and prior transient ischemic attacks.

\section{Adverse Events}

At least one treatment-emergent adverse event occurred in $224(93.3 \%)$ patients (Table 3$)$. The most commonly reported adverse event was headache, ranging in incidence from $21.3 \%$ to 


\section{Table 1: Patient Disposition}

\begin{tabular}{|c|c|c|c|c|}
\hline \multirow[b]{2}{*}{ Patient Disposition } & \multirow[b]{2}{*}{ Placebo } & \multicolumn{3}{|c|}{ Repinotan Dose } \\
\hline & & $0.5 \mathrm{mg} / \mathrm{d}$ & $1.25 \mathrm{mg} / \mathrm{d}$ & $2.5 \mathrm{mg} / \mathrm{d}$ \\
\hline Randomized & 58 & 61 & 61 & 60 \\
\hline Withdrawn & $15(25.9 \%)$ & $9(14.8 \%)$ & $13(21.3 \%)$ & $13(21.7 \%)$ \\
\hline Adverse event & $1(1.7 \%)$ & $0(0.0 \%)$ & $2(3.3 \%)$ & $0(0.0 \%)$ \\
\hline Consent withdrawn & $0(0.0 \%)$ & $0(0.0 \%)$ & $0(0.0 \%)$ & $2(3.3 \%)$ \\
\hline Lost to follow-up & $2(3.4 \%)$ & $0(0.0 \%)$ & $0(0.0 \%)$ & $0(0.0 \%)$ \\
\hline Per-protocol analysis & $52(89.7 \%)$ & $58(95.1 \%)$ & $41(67.2 \%)$ & $36(60.0 \%)$ \\
\hline \multicolumn{5}{|c|}{ Reason for exclusion from per-protocol analysis } \\
\hline Adverse event & $2(3.4 \%)$ & $1(1.6 \%)$ & $5(8.2 \%)$ & $0(0.0 \%)$ \\
\hline Death & $2(3.4 \%)$ & $1(1.6 \%)$ & $2(3.3 \%)$ & $0(0.0 \%)$ \\
\hline
\end{tabular}

$35.0 \%$ with repinotan and $24.1 \%$ in the placebo group. Most adverse events were of mild or moderate severity; 59 (25\%) patients reported at least one severe adverse event. The most common severe adverse events were neurological worsening, cerebral hemorrhage, and brain edema. Thirteen patients discontinued treatment for adverse events (Table 4). Most were considered either remotely related or unrelated to study treatment.

\section{Safety Evaluations}

Of $46(19.2 \%)$ patients who died, 43 died within 30 days of the end of the repinotan infusion and three died beyond 30 days. Mortality rates were $22.4 \%$ in the placebo group, $14.8 \%$ in the $0.5 \mathrm{mg} / \mathrm{d}$ group, $21.3 \%$ in the $1.25 \mathrm{mg} / \mathrm{d}$ group, and $18.3 \%$ in the $2.5 \mathrm{mg} / \mathrm{d}$ group. The cause of death was most commonly reported as cerebral edema/herniation or cardiac, including cardiopulmonary arrest, myocardial infarction, and congestive

\section{Table 2: Baseline Demographic and Clinical Characteristics of the Safety Population}

\begin{tabular}{|c|c|c|c|c|}
\hline \multirow[b]{2}{*}{ Characteristic } & \multirow[b]{2}{*}{ Placebo } & \multicolumn{3}{|c|}{ Repinotan Dose } \\
\hline & & $0.5 \mathrm{mg} / \mathrm{d}$ & $1.25 \mathrm{mg} / \mathrm{d}$ & $2.5 \mathrm{mg} / \mathrm{d}$ \\
\hline Number of patients & 58 & 61 & 61 & 60 \\
\hline Age $(y r)$, Mean $\pm S D$ & $69.4 \pm 13.9$ & $72.9 \pm 11.6$ & $71.2 \pm 10.8$ & $68.8 \pm 12.9$ \\
\hline Weight (kg), Mean \pm SD & $71.2 \pm 14.6$ & $77.4 \pm 17.6$ & $74.4 \pm 19.0$ & $75.4 \pm 18.0$ \\
\hline Male $(\%)$ & $32(55.2 \%)$ & $40(65.6 \%)$ & $31(50.8 \%)$ & $33(55.0 \%)$ \\
\hline \multicolumn{5}{|l|}{ Ethnicity } \\
\hline Caucasian & $47(81.0 \%)$ & $51(83.6 \%)$ & $50(82.0 \%)$ & $45(75.0 \%)$ \\
\hline Asian & $4(6.9 \%)$ & $4(6.6 \%)$ & $4(6.6 \%)$ & $4(6.7 \%)$ \\
\hline Black & $3(5.2 \%)$ & $0(0.0 \%)$ & $2(3.3 \%)$ & $4(6.7 \%)$ \\
\hline Other & $4(6.9 \%)$ & $6(9.8 \%)$ & $5(8.2 \%)$ & $7(11.7 \%)$ \\
\hline Prior neurologic disability & $4(6.9 \%)$ & $6(9.8 \%)$ & $6(9.8 \%)$ & $7(11.7 \%)$ \\
\hline Prior stroke & $9(15.5 \%)$ & $11(18.0 \%)$ & $12(19.7 \%)$ & $13(21.7 \%)$ \\
\hline Prior transient ischemic attack & $9(15.5 \%)$ & $13(21.3 \%)$ & $10(16.4 \%)$ & $18(30.0 \%)$ \\
\hline Mean (SD) NIH-SS & $13.4 \pm 6.0$ & $13.5 \pm 5.1$ & $13.3 \pm 5.3$ & $13.4 \pm 5.5$ \\
\hline Historical Rankin $=0$ & $51(87.9 \%)$ & $49(80.3 \%)$ & $56(91.8 \%)$ & $52(86.7 \%)$ \\
\hline Mean (SD) time to infusion (h) & $5.1 \pm 1.0$ & $5.0 \pm 0.8$ & $5.0 \pm 0.9$ & $5.0 \pm 1.1$ \\
\hline Mean (SD) duration of treatment (h) & $68.3 \pm 13.6$ & $70.1 \pm 9.1$ & $57.3 \pm 24.4$ & $49.6 \pm 30.1$ \\
\hline
\end{tabular}


Table 3: Adverse Events Occurring in a Repinotan Treatment Arm at a Higher Rate Than Placebo and an Incidence of at Least $10 \%$ in Any One Dose

\begin{tabular}{|c|c|c|c|c|}
\hline & \multirow[b]{2}{*}{$\begin{array}{l}\text { Placebo } \\
(\mathbf{n}=58)\end{array}$} & \multicolumn{3}{|c|}{ Repinotan Dose } \\
\hline & & $\begin{array}{c}0.5 \mathrm{mg} / \mathrm{d} \\
(\mathrm{n}=61)\end{array}$ & $\begin{array}{c}1.25 \mathrm{mg} / \mathrm{d} \\
(\mathrm{n}=61)\end{array}$ & $\begin{array}{c}2.5 \mathrm{mg} / \mathrm{d} \\
(\mathrm{n}=60)\end{array}$ \\
\hline Any adverse event & $51(87.9 \%)$ & $57(93.4 \%)$ & $56(91.8 \%)$ & $60(100 \%)$ \\
\hline Serious event & $15(25.9 \%)$ & $8(13.1 \%)$ & $14(23.0 \%)$ & $21(35.0 \%)$ \\
\hline Abdominal pain & $0(0.0 \%)$ & $3(4.9 \%)$ & $4(6.6 \%)$ & $7(11.7 \%)$ \\
\hline Agitation & $3(5.2 \%)$ & $6(9.8 \%)$ & $6(9.8 \%)$ & $8(13.3 \%)$ \\
\hline Chest pain & $2(3.4 \%)$ & $2(3.3 \%)$ & $7(11.5 \%)$ & $9(15.0 \%)$ \\
\hline Confusion & $3(5.2 \%)$ & $7(11.5 \%)$ & $2(3.3 \%)$ & $6(10.0 \%)$ \\
\hline Constipation & $6(10.3 \%)$ & $6(9.8 \%)$ & $2(3.3 \%)$ & $8(13.3 \%)$ \\
\hline Cough increased & $3(5.2 \%)$ & $4(6.6 \%)$ & $5(8.2 \%)$ & $8(13.3 \%)$ \\
\hline Headache & $14(24.1 \%)$ & $21(34.4 \%)$ & $13(21.3 \%)$ & $21(35.0 \%)$ \\
\hline Hematuria & $5(8.6 \%)$ & $5(8.2 \%)$ & $6(9.8 \%)$ & $7(11.7 \%)$ \\
\hline Neck pain & $2(3.4 \%)$ & $7(11.5 \%)$ & $1(1.6 \%)$ & $3(5.0 \%)$ \\
\hline Nervousness & $2(3.4 \%)$ & $9(14.8 \%)$ & $5(8.2 \%)$ & $6(10.0 \%)$ \\
\hline Neurological worsening & $10(17.2 \%)$ & $10(16.4 \%)$ & $13(21.3 \%)$ & $19(31.7 \%)$ \\
\hline Pain & $6(10.3 \%)$ & $10(16.4 \%)$ & $8(13.1 \%)$ & $4(6.7 \%)$ \\
\hline Peripheral edema & $3(5.2 \%)$ & $5(8.2 \%)$ & $5(8.2 \%)$ & $9(15.0 \%)$ \\
\hline Somnolence & $4(6.9 \%)$ & $11(18.0 \%)$ & $5(8.2 \%)$ & $1(1.7 \%)$ \\
\hline Urinary incontinence & $6(10.3 \%)$ & $12(19.7 \%)$ & $6(9.8 \%)$ & $7(11.7 \%)$ \\
\hline Vomiting & $5(8.6 \%)$ & $5(8.2 \%)$ & $9(14.8 \%)$ & $12(20.0 \%)$ \\
\hline
\end{tabular}

heart failure. Respiratory failure, recurrent stroke, progression of stroke, pneumonia, and sepsis were also reported as causes of death. No differences across treatment groups were noted in the types of events reported as the cause of death.

For most laboratory parameters, changes from baseline were small and not clinically relevant. Liver function tests that were $\geq 3$ times the upper limit of normal were reported in five patients in the repinotan $2.5 \mathrm{mg} / \mathrm{d}$ group, three in the $1.25 \mathrm{mg} / \mathrm{d}$ group, and one each in the $0.5 \mathrm{mg} / \mathrm{d}$ and placebo groups.

Fluctuations in systolic and diastolic blood pressure were observed across all treatment groups and ranged between -3.4 and $-11.4 \mathrm{~mm} \mathrm{Hg}$, but there were no clinically relevant differences among the groups. Mean changes from baseline in heart rate ranged from 0 to -5 beats/minute and were similar across the treatment groups at each time point. Mean changes in ECG P-R, QRS, and Q-T intervals at the 24- and 96-hour time points approximated 0 for all treatment groups with no differences among the groups.

\section{Outcome Assessments}

No significant differences were observed in relative risk $(95 \%$ CI) of treatment failure between any dose of repinotan and placebo at either four weeks or three months (Table 5). The highest NIH-SS success rates at four weeks and three months
Table 4: Adverse Events Causing Premature Discontinuation From Treatment

\begin{tabular}{ll}
\hline Placebo & Severe neurological worsening \\
& Heart arrest and death \\
& Severe cerebral infarct and death \\
& Cerebral hemorrhage, coma, and death \\
& Moderate myocardial ischemia \\
Repinotan $0.5 \mathrm{mg} / \mathrm{d}$ & Severe neurological worsening and death \\
& Severe brain edema with moderate \\
Repinotan $1.25 \mathrm{mg} / \mathrm{d}$ & worsening \\
& Severe pulmonary edema \\
& Mild agitation, vomiting, hypertension, \\
& and moderate headache \\
& Severe intracranial hemorrhage and death \\
& Severe neurological worsening, cerebral \\
& hemorrhage, and death \\
& Neurological worsening, hemorrhage, and \\
death & Severe cerebrovascular accident \\
& None
\end{tabular}


Table 5: Outcome at 4 Weeks and 3 Months Post Treatment in the ITT Population*

\begin{tabular}{|c|c|c|c|c|c|c|c|}
\hline \multirow{3}{*}{ NIH-SS } & \multirow[b]{2}{*}{ Placebo } & \multicolumn{2}{|c|}{ Repinotan 0.5 mg/day } & \multicolumn{2}{|c|}{ Repinotan 1.25 mg/day } & \multicolumn{2}{|c|}{ Repinotan $2.5 \mathrm{mg} / \mathrm{day}$} \\
\hline & & Success Rate & RR $(95 \% \mathrm{CI})$ & Success Rate & RR $(95 \%$ CI $)$ & Success Rate & RR $(95 \% \mathrm{CI})$ \\
\hline & & & 0.89 & & 0.87 & & 1.17 \\
\hline 4 weeks & $35(60.3)$ & $38(62.3)$ & $(0.56-1.43)$ & $40(65.6)$ & $(0.54-1.39)$ & $31(51.7)$ & $(0.77-1.79)$ \\
\hline p-value & & & 0.65 & & 0.56 & & 0.46 \\
\hline NIH-SS & & & 0.73 & & 0.85 & & 0.91 \\
\hline 3 months & $34(58.6)$ & $43(70.5)$ & $(0.44-1.21)$ & $40(65.5)$ & $(0.53-1.36)$ & $38(63.3)$ & $(0.57-1.44)$ \\
\hline p-value & & & 0.22 & & 0.51 & & 0.68 \\
\hline Barthel Index & & & 1.07 & & 0.95 & & 0.98 \\
\hline 4 weeks & $20(34.5)$ & $18(29.5)$ & $(0.83-1.37)$ & $23(37.7)$ & $(0.73-1.25)$ & $21(35.0)$ & $(0.75-1.28)$ \\
\hline p-value & & & 0.60 & & 0.72 & & 0.90 \\
\hline Barthel Index & & & 1.13 & & 0.98 & & 1.06 \\
\hline 3 months & $27(46.6)$ & $24(39.3)$ & $(0.83-1.55)$ & $29(47.5)$ & $(0.70-1.38)$ & $26(43.3)$ & $(0.77-1.47)$ \\
\hline p-value & & & 0.43 & & 0.91 & & 0.73 \\
\hline Rankin Score & & & 1.19 & & 1.08 & & 1.17 \\
\hline 4 weeks & $15(25.9)$ & $7(11.5)$ & $(1.00-1.42)$ & $12(19.7)$ & $(0.89-1.32)$ & $8(13.3)$ & $(0.97-1.40)$ \\
\hline p-value & & & 0.05 & & 0.42 & & 0.10 \\
\hline Rankin Score & & & 1.14 & & 1.02 & & 1.04 \\
\hline 3 months & $17(29.3)$ & $12(19.7)$ & $(0.92-1.40)$ & $17(27.9)$ & $(0.81-1.28)$ & $16(26.7)$ & $(0.83-1.30)$ \\
\hline p-value & & & 0.22 & & 0.86 & & 0.75 \\
\hline
\end{tabular}

*Success was measured by the NIH-SS ( $\geq 4$ point improvement or a return to a score of 0 or 1 ), Barthel Index (score of 85 to 100 ) and modified Rankin Score (score of 0 or 1). P-value, Mantel-Haenszel chi-square test for active treatment minus placebo.

were seen in the $0.5 \mathrm{mg} / \mathrm{d}$ and $1.25 \mathrm{mg} / \mathrm{d}$ repinotan dose groups (Table 5). A trend toward improvement on the NIH-SS at three months was observed for all active treatment groups relative to placebo. The highest Barthel Index success rates at the four-week and three-month evaluations were observed in the $1.25 \mathrm{mg} / \mathrm{d}$ repinotan dose group (Table 5). The success rates for the modified Rankin scale at the four-week and three-month evaluations were lower in all repinotan treatment groups compared with the placebo group (Table 5). However, the best outcome was observed at the repinotan $1.25 \mathrm{mg} / \mathrm{d}$ dose.

\section{Discussion}

The primary objective of this study was to investigate the tolerability and safety of three doses of repinotan administered as a continuous infusion over 72 hours in patients within six hours of onset of symptoms of an acute ischemic stroke. All treatment groups were comparable at baseline for severity of stroke. The placebo group had the lowest rate of previous transient ischemic attack or stroke and previous stroke disability, which may have affected outcomes. This imbalance may have been due to chance or possibly have resulted from the randomization procedure. Patients were excluded from participation if they received t-PA, because its use for acute stroke was investigational in Canada at the time of this study. This may have affected the selection of patients for inclusion in the study as few patients were treated within the first three hours of symptom onset. The mean time to treatment was $5.0 \pm 0.9$ hours, and this late treatment may have diminished efficacy signals.
Because this study was not powered to establish efficacy, signals of efficacy must be interpreted cautiously as exploratory data; however, the results from the ITT analysis suggest that repinotan may improve functional and neurological outcomes at three months. Although no significant differences were observed, the highest success rates were observed with the 1.25 $\mathrm{mg} / \mathrm{d}$ dose of repinotan. One explanation for the lack of significant improvement with repinotan was the higher than expected placebo success rates on all three assessment scales. ${ }^{22}$ The relatively modest and nonsignificant differences in outcome between placebo and repinotan groups may be attributed to a number of factors, including a sample size designed to evaluate safety rather than efficacy, patient selection criteria, and a late mean time to treatment. ${ }^{22-24}$ A recently initiated study of IV magnesium for acute stroke estimated that 2700 patients were required to detect a $5.5 \%$ absolute difference between active treatment and placebo. ${ }^{25}$ A post hoc analysis from a recent failed trial of citicoline observed greater absolute difference in outcomes between active treatment and placebo groups when patients with mild strokes were excluded. ${ }^{4}$

In conclusion, repinotan was safe and well-tolerated in this population of stroke patients. Compared with placebo, repinotan exhibited an acceptable tolerability profile with adverse events that mostly related to known serotonergic activity. The results suggest that the $1.25 \mathrm{mg} / \mathrm{d}$ dose of repinotan offers a balance of pharmacologic effect and tolerability. The future development of repinotan for acute ischemic stroke will require larger studies to evaluate efficacy. A phase IIb trial of approximately 700 patients will be completed in 2004 . 


\section{ACKNOWLEDGEMENTS}

There has been no direct industry support for any of the authors. All of the authors were investigators in the Repinotan Trial and therefore their sites received the standard per patient reimbursements for patients enrolled in the trial. These funds were used to pay institutional overhead, pay the cost of lab and X-rays, pay for the study coordinator and the costs of running a clinical trial office. These payments were the same for all sites in Canada. As chairman of the steering committee for the study I received reimbursement for travel expenses to Steering committee meetings but did not receive any honorariums. There has been no other financial support for the manuscript. Richard Perry of Parexel provided editorial assistance on the manuscript. The study sponsors did not edit the manuscript prior to submission.

\section{REFERENCES}

1. American Heart Association. Heart and Stroke Statistical Update. Available at: http://www.americanheart.org/statistics/10econom.html, 2003.

2. The National Institute of Neurological Disorders and Stroke rt-PA Stroke Study Group. Tissue plasminogen activator for acute ischemic stroke. N Engl J Med 1995;333:1581-1587.

3. Clark WM, Raps EC, Tong DC, Kelly RE. Cervene (Nalmefene) in acute ischemic stroke : final results of a phase III efficacy study. The Cervene Stroke Study Investigators. Stroke 2000;31:12341239.

4. Clark WM, Williams BJ, Selzer KA, et al. A randomized efficacy trial of citicoline in patients with acute ischemic stroke. Stroke 1999;30:2592-2597.

5. Sherman DG, Atkinson RP, Chippendale T, et al. Intravenous ancrod for treatment of acute ischemic stroke: the STAT study: a randomized controlled trial. Stroke Treatment with Ancrod Trial. JAMA2000;283:2395-2403.

6. Wahlgren NG, Ranasinha KW, Rosolacci T, et al. Clomethiazole acute stroke study (CLASS): results of a randomized, controlled trial of clomethiazole versus placebo in 1360 acute stroke patients. Stroke 1999;30:21-28

7. De Deyn PP, Reuck JD, Deberdt W, Vlietinck R, Orgogozo JM. Treatment of acute ischemic stroke with piracetam. Members of the Piracetam in Acute Stroke Study (PASS) Group. Stroke 1997;28:2347-2352.

8. Albers GW, Goldstein LB, Hall D, Lesko LM. Aptiganel hydrochloride in acute ischemic stroke: a randomized controlled trial. JAMA2001;286:2673-2682.

9. Clark WM, Wechsler LR, Sabounjian LA, Schwiderski UE. A phase III randomized efficacy trial of $2000 \mathrm{mg}$ citicoline in acute ischemic stroke patients. Neurology 2001;57:1595-1602.
10. Diener HC. Multinational randomised controlled trial of lubeluzole in acute ischaemic stroke. European and Australian Lubeluzole Ischaemic Stroke Study Group. Cerebrovasc Dis 1998;8:172-181.

11. Diener HC, Cortens M, Ford G, et al. Lubeluzole in acute ischemic stroke treatment: A double-blind study with an 8-hour inclusion window comparing a $10-\mathrm{mg}$ daily dose of lubeluzole with placebo. Stroke 2000;31:2543-2551.

12. Enlimomab Acute Stroke Trial Investigators. Use of anti-ICAM-1 therapy in ischemic stroke: results of the Enlimomab Acute Stroke Trial. Neurology 2001;57:1428-1434.

13. Sacco RL, DeRosa JT, Haley EC, Jr., et al. Glycine antagonist in neuroprotection for patients with acute stroke: GAIN Americas: a randomized controlled trial. JAMA2001;285:1719-1728.

14. Lees KR, Asplund K, Carolei A, et al. Glycine antagonist (gavestinel) in neuroprotection (GAIN International) in patients with acute stroke: a randomised controlled trial. GAIN International Investigators. Lancet 2000;355:1949-1954.

15. De Vry J, Dietrich H, Glaser T, et al. BAY-X3702. Drugs Future 1997;22:341-349.

16. Horvath E, Augstein KH, Wittka R. Neuroprotective effect of the novel $5-\mathrm{HT}_{1 \mathrm{~A}}$ receptor agonist BAY x 3702 in a rat model of permanent focal cerebral ischemia and traumatic brain injury. Soc Neurosci 1997;23:1923 (abstract).

17. Horvath E, Augstein KH. Neuroprotective effect of the novel 5$\mathrm{HT}_{1 \mathrm{~A}}$ receptor agonist BAY $\mathrm{x} 3702$ in the rat model of acute subdural hematoma. Neurotrauma 1997;14:800 (abstract).

18. Fleckenstein L, Roche L, Sundaresan PR, et al. Ascending-dose safety and tolerability study of BAY x 3702 in healthy elderly males and females. Clin Pharmacol Ther 1998;63:190.

19. Brott T, Adams HP, Jr., Olinger CP, et al. Measurements of acute cerebral infarction: a clinical examination scale. Stroke 1989;20:864-870.

20. de Haan R, Limburg M, Bossuyt P, van der Meulen J, Aaronson N. The clinical meaning of Rankin 'handicap' grades after stroke. Stroke 1995;26:2027-2030.

21. Mahoney FI, Barthel DW. Functional evaluation: the Barthel Index. Md State Med J 1965;14:61-65.

22. Duncan PW, Jorgensen HS, Wade DT. Outcome measures in acute stroke trials: a systematic review and some recommendations to improve practice. Stroke 2000;31:1429-1438.

23. Uchino K, Billheimer D, Cramer SC. Entry criteria and baseline characteristics predict outcome in acute stroke trials. Stroke 2001:32:909-916.

24. Muir KW, Grosset DG. Neuroprotection for acute stroke: making clinical trials work. Stroke 1999;30:180-182.

25. Bradford A, Lees K. Design of the Intravenous Magnesium Efficacy in Acute Stroke (IMAGES) trial. Curr Control Trials Cardiovasc Med 2000;1:184-190. 